\title{
Immunological Responses to L-Asparaginase
}

\author{
Robert G. Peterson, Robert E. Handschumacher, and \\ Malcolm S. Mrtchell \\ From the Departments of Pharmacology and Medicine, Yale University School \\ of Medicine, New Haven, Connecticut 06510
}

\begin{abstract}
A в S T RACT In a series of 40 patients treated with L-asparaginase for various neoplastic diseases, 6 patients had generalized anaphylactic reactions to L-asparaginase. Each of these reactors had antibodies detectable by passive hemagglutination, but precipitins were detectable in only one of this group of six patients. That patient had received two courses of the enzyme. 1 wk after the anaphylactic reaction, complement-fixing antibodies were present in all the patients that were studied. Specific reagin antibodies ( $\operatorname{IgE}$ ) were demonstrated in one patient by the release of histamine from his leukocytes after incubation in vitro with L-asparaginase.

Binding of L-asparaginase to serum antibodies after incubation in vitro was detected by selective precipitation of the complexes with $30 \%$ ammonium sulfate or by ultracentrifugation. Total inactivation of the enzyme did not occur even at optimal proportions or at antibody excess.
\end{abstract}

Passive hemagglutinating antibodies to L-asparaginase were present in all patients who had an allergic reaction at least 1 day before the reaction occurred, when that sample was available, and were absent in all patients who did not manifest clinical allergy. Titration of antibodies by passive hemagglutination may thus provide a means of predicting impending anaphylaxis in this system, particularly when coupled with a sudden decrease in circulating levels of L-asparaginase activity.

\section{INTRODUCTION}

Therapy with the enzyme L-asparaginase (Asnase) ${ }^{1}$ from Escherichia coli is an effective means of inducing remission in many patients with acute lymphoblastic and occasional patients with myeloblastic leukemia (1-12). Since the Asnase preparation is a bacterial protein with a molecular weight of about 130,000 (13) and is immuno-

Received for publication 28 October 1970 and in revised form 28 December 1970.

${ }^{1}$ Abbreviations used in this paper: Asnase, L-asparaginase ; GRBC, goat red blood cells; ME, mercaptoethanol; PBS, phosphate-buffered saline. genic in animals (14-16), it could be anticipated that a number of patients treated with this agent would develop allergic reactions. In general these have not been severe, but several cases of anaphylactic shock have been reported $(4,8,17)$ including a number in our own study $(5,12)$.

This report deals with the identification of antibodies formed in man as a result of therapy with Asnase. In particular, it has been found that the presence of passive hemagglutinating antibodies was predictive of impending anaphylaxis especially when such a titer was accompanied by rapid disappearance of the enzyme from the circulation.

\section{METHODS}

Source of L-asparaginase. Asnase from $E$. coli used in this study was obtained from E. R. Squibb \& Sons (New York), $180 \mathrm{IU} / \mathrm{mg}$ (lots As335-712/15-S-3, 15-S-7, and $15 \mathrm{~T}$ ), as well as from Merck Sharp \& Dohme (West Point, $\mathrm{Pa}$ ), $270 \mathrm{IU} / \mathrm{mg}$ (lot C-7941). Erzeinia carotovora Asnase was kindly provided by Dr. H. E. Wade of the British Microbiological Research Establishment, $50 \mathrm{IU} / \mathrm{mg}$. All enzyme was supplied as lyophilized powder, which was reconstituted with sterile physiological saline without preservative, immediately before its use.

Assay for enzymatic activity. Enzymatic activity of serum samples was determined by the coupled enzyme reaction of Cooney and Handschumacher $(18,19)$. The activity was also measured by quantitating the catalytic decomposition of 5-diazo-4-oxo-L-norvaline at $274 \mathrm{~nm}(20)$. Both assays were standardized against the Nessler method for the determination of ammonia released from L-asparagine (20).

Patients. (Table I). Treatment of patients with Asnase followed the protocol reported by Capizzi et al. (12). $\mathrm{Pa}$ tients with acute lymphoblastic leukemia received either $200 \mathrm{IU} / \mathrm{kg}$ daily for 20 days or $400 \mathrm{IU} / \mathrm{kg}$ on Monday and Wednesday and $600 \mathrm{IU} / \mathrm{kg}$ on Friday for $3 \mathrm{wk}$, unless severe allergic reactions forced cessation of therapy. One patient (A. R.) with malignant melanoma was also treated according to this schedule with $200 \mathrm{IU} / \mathrm{kg}$ per day. Patients with acute myelocytic, monocytic, or myelomonocytic leukemia received $1000 \mathrm{IU} / \mathrm{kg}$ on 2 successive days only. The enzyme was given by slow intravenous injection. Serum samples were collected daily before the administration of enzyme and 
TABLE I

Summary_of Patients with Immunological Responses

\begin{tabular}{|c|c|c|c|c|c|c|c|c|c|}
\hline Patient & Age & Sex & Diagnosis* & Course & $\begin{array}{l}\text { Asnase } \\
\text { dose }\end{array}$ & $\begin{array}{c}\text { Passive } \\
\text { hemagglu- } \\
\text { tination }\end{array}$ & $\begin{array}{l}\text { Complement } \\
\text { fixation }\end{array}$ & $\begin{array}{l}\text { Precipitin } \\
\text { reaction }\end{array}$ & Remarks \\
\hline & $y r$ & & & & $\begin{array}{l}I U / \mathrm{kg} \\
\text { per day }\end{array}$ & & & & \\
\hline \multirow[t]{2}{*}{ E. S. } & 5 & $\mathrm{~F}$ & ALL & 1 & 10 & - & ND & - & Uneventful \\
\hline & & & & 2 & 200 & + & + & + & Anaphylaxis \\
\hline A. $\mathrm{R}$. & 28 & $\mathbf{M}$ & MM & 1 & 200 & + & + & - & Anaphylaxis \\
\hline L. T. & 16 & F & ALL & 1 & 200 & + & + & - & $\begin{array}{l}\text { Urticaria, } \\
\text { anaphylaxis }\end{array}$ \\
\hline \multirow[t]{2}{*}{ V. W. } & 13 & $F$ & ALL & 1 & 200 & - & ND & - & $\begin{array}{c}\text { Decreased } \\
\text { enzyme } \\
\text { activity } \\
\text { only }\end{array}$ \\
\hline & & & & 2 & 200 & + & ND & - & $\begin{array}{l}\text { Therapy } \\
\text { discontinued }\end{array}$ \\
\hline F. Q. & 24 & $\mathrm{~F}$ & ALL & 1 & 200 & + & + & - & Anaphylaxis \\
\hline A. G. & 5 & M & ALL & 1 & $400 \ddagger$ & + & ND & - & $\begin{array}{l}\text { Therapy } \\
\text { discontinued }\end{array}$ \\
\hline P. A. & 11 & $\mathrm{~F}$ & ALL & 1 & $400 \ddagger$ & + & ND & ND & $\begin{array}{l}\text { Mild } \\
\text { anaphylaxis }\end{array}$ \\
\hline D. I. & 35 & $\mathbf{M}$ & ALL & 1 & $400 \ddagger$ & + & ND & ND & Anaphylaxis \\
\hline W. S. & 15 & $\mathbf{M}$ & ALL & 1 & $400 \ddagger$ & + & ND & ND & $\begin{array}{l}\text { Therapy } \\
\text { discontinued }\end{array}$ \\
\hline R. P. & 56 & $\mathbf{M}$ & AMoL & 1 & 1000 & + & + & ND & $\begin{array}{c}\text { Hypotension } \\
1 \mathrm{hr} \text { post- } \\
\text { injection; } \\
\text { therapy } \\
\text { discontinued }\end{array}$ \\
\hline D. C. & 62 & $\mathrm{~F}$ & AMyL & 1 & $1000 \S$ & + & ND & ND & $\begin{array}{l}\text { Titer } \\
\text { developed } \\
1 \text { wk after } \\
\text { last dose }\end{array}$ \\
\hline
\end{tabular}

*ALL, acute lymphocytic leukemia; AMoL, acute monocytic leukemia; AMyL, acute myelocytic leukemia; MM, malignant melanoma; ND, not done.

$\ddagger$ Doses on Monday and Wednesday; $600 \mathrm{IU} / \mathrm{kg}$ Friday only.

$\S$ Doses on days 1 and 2 only.

were either assayed immediately for Asnase activity or rapidly frozen at $-18^{\circ} \mathrm{C}$ and assayed within $24 \mathrm{hr}$.

Titration of antibodies. Passive hemagglutination titers were determined by the method of Stavitsky (21) with the following modifications. Formalinized goat red blood cells (GRBC), from Difco Labs (Detroit, Mich.) were washed four times in $0.85 \%$. saline and were treated at a concentration of $2.5 \%(\mathrm{v} / \mathrm{v})$ with an equal volume of tannic acid $(0.5 \mathrm{mg} / \mathrm{ml})$. The cells were washed with phosphate-buffered saline (PBS) containing $\mathrm{NaCl}$ ( 0.154 moles/liter) and phosphate ( 0.075 moles/liter, $\mathrm{pH} 6.4)$, and resuspended at a concentration of $5 \%(\mathrm{v} / \mathrm{v})$ in $\mathrm{PBS}$. An equal volume of PBS containing Asnase ( 1 or $2 \mathrm{mg} / \mathrm{ml}$ ) was then added to coat ("sensitize") the tanned RBC. The sensitized cells were washed once in $0.85 \%$ saline containing $0.5 \%(\mathrm{v} / \mathrm{v})$ normal rabbit serum and used as a $1.25 \%$. suspension in $0.85 \%$ saline containing $1 \%$ normal rabbit serum. With the addition of merthiolate $1: 10,000$ as a preservative, this reagent was stable at $4^{\circ} \mathrm{C}$ for at least $4 \mathrm{wk}$. Sera from patients were heated at $56^{\circ} \mathrm{C}$ for $30 \mathrm{~min}$ to inactivate com- plement and reduce nonspecific agglutination. To assure complete removal of "nonspecific" agglutinins, the packed RBC from $1 \mathrm{ml}$ of a $1.25 \%$ suspension of unsensitized tanned GRBC were incubated for $15 \mathrm{~min}$ at $25^{\circ} \mathrm{C}$ with 0.2 $\mathrm{ml}$ of serum and centrifuged; this procedure was repeated if necessary. ${ }^{2}$

Twofold serial dilutions of serum were made with $25-\mu 1$ Takatsy diluters in microtrays (Linbro Chemical Co., New Haven, Conn.) with $0.85 \%$ saline containing $1 \%$ normal rabbit serum as the diluent. $25 \mu 1$ of a $1.25 \%$. suspension of sensitized GRBC were added, the trays were shaken, and the reaction was read in 60-90 min. Negative controls of serum with unsensitized cells and diluent alone with sensi-

${ }^{2}$ Among patients with solid tumors in a previous study (22) only about one-third required such absorption (Mitchell, M. S. Unpublished observations.). The possible significance of the high proportion of sera from leukemic patients with Forssman, or perhaps heterophile, agglutinins in this study is being investigated. 

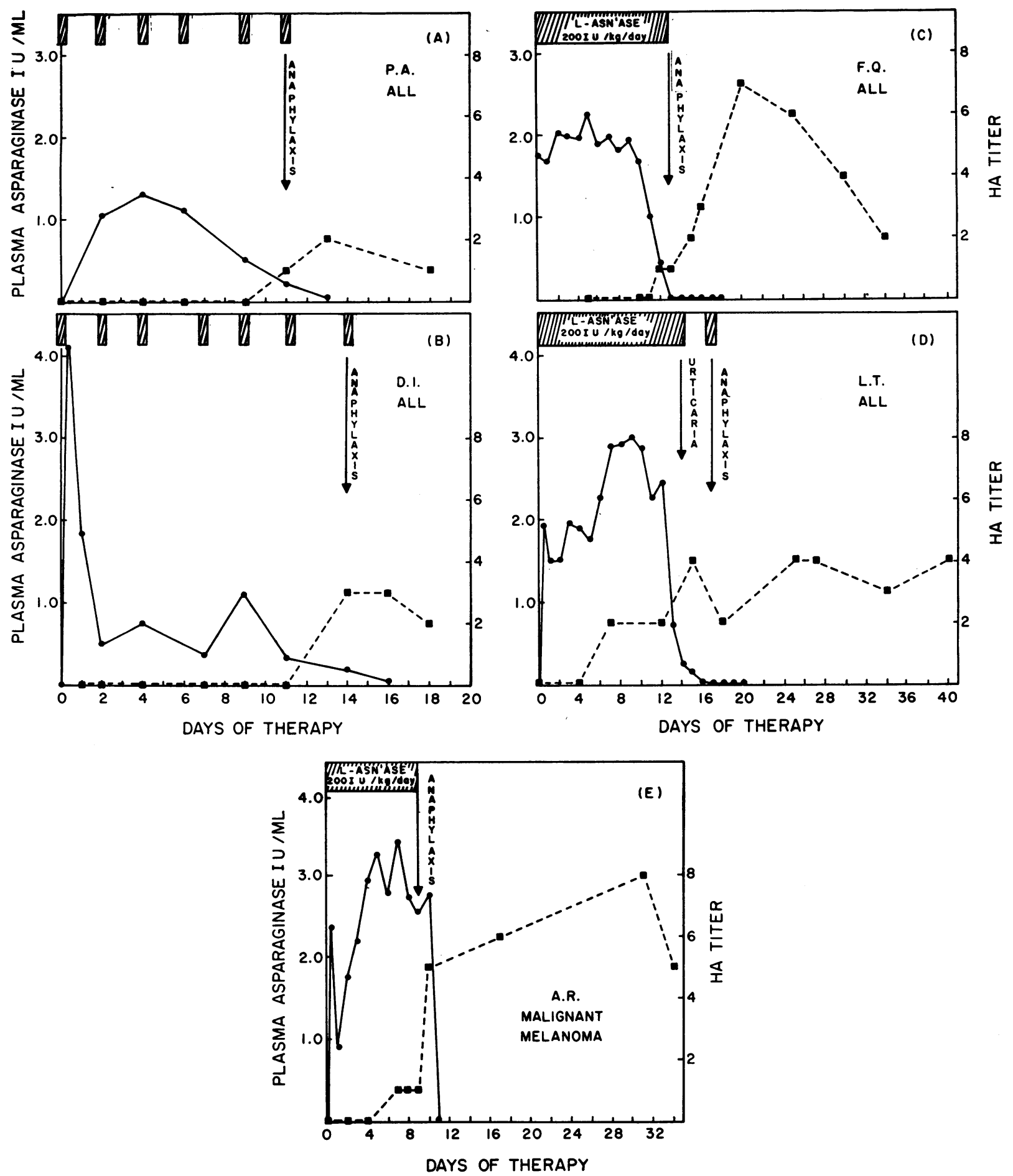

Figure 1 Comparison of enzyme level and immune response. E. coli L-asparaginase was administered by intravenous injection on the days specified by hatched boxes at top of graphs. Doses for graphs (A) and (B) are given in Table I. The solid line represents enzymatic activity and the broken line passive hemagglutination (HA) titer. 
tized cells were included. To determine reproducibility, a hyperimmune rabbit antiserum to Asnase was also included in each set of titrations as a standard. The endpoint chosen was the last well showing a ring of unagglutinated cells surrounding a mat of agglutinated cells, and designated " $1+$ " agglutination. The titer was expressed as the $\log _{2}$ of the reciprocal of the dilution of antiserum present at the endpoint. Thus, a titer of 4 represents an endpoint dilution of $1: 16$.

For precipitin studies "Pattern A" agar plates were purchased from Hyland Laboratories (Los Angeles, Calif.). Asnase preparations $(0-50 \mu \mathrm{g})$ were added to the surrounding wells, and undiluted serum was placed in the center well. The plates were incubated at $4^{\circ} \mathrm{C}$ for $48 \mathrm{hr}$ in a humidified chamber, and any precipitation lines were photographed unstained.

The method described by Levine (23) was used to study complement fixation. The release of histamine from leukocytes sensitized with antibody in vivo was used to attempt to demonstrate specific $\operatorname{IgE}$ antibody against Asnase according to the method of Lichtenstein and Osler (24). $15,000,000$ washed leukocytes per incubation flask were exposed to varying concentrations of Asnase at $37^{\circ} \mathrm{C}$ for 60 min. The histamine content of each sample was assayed by Dr. Elizabeth Gillespie by the method of Shore, Burkhalter, and Cohn (25) with the modification of Kremzner and Wilson (26) using phosphoric acid to stabilize the fluorescent product after acidification of samples to $\mathrm{pH} 2.0$ and storage overnight at $-20^{\circ} \mathrm{C}$. Total IgE content was assayed by microprecipitation in agar by Dr. Douglas Heiner, Torrance General Hospital, Torrance, Calif.

The presence of IgG, IgM, and IgA immunoglobulins in precipitates was determined with specific goat antisera prepared against purified human immunoglobulins (Hyland Laboratories). Distinction of $\operatorname{IgM}$ from IgG in passive hemagglutination reactions was made by means of mercaptoethanol (ME) degradation (27) as well as sucrose gradient ultracentrifugation in a Beckman model L2-65B with an SW65 Titanium rotor.

Hyperimmune sera were prepared in $4 \mathrm{~kg}$ female, New Zealand white rabbits that were immunized by subcutaneous interscapular injection of $5 \mathrm{mg}$ Asnase in Freund's complete adjuvant $(4 \mathrm{ml})$. Subsequent intravenous booster injections were given 6,7 , and 8 wk after initial immunization. The hyperimmunized animals were anesthetized and exsanguirated; sera from these rabbits were heated to $56^{\circ} \mathrm{C}$ for 30 min and then frozen in small portions at $-70^{\circ} \mathrm{C}$.

To demonstrate active enzyme-antibody complexes, $0.5 \mathrm{ml}$ of human or rabbit antiserum was incubated with $2.0 \mathrm{IU}$ Asnase for $15 \mathrm{~min}$ at $4^{\circ} \mathrm{C}$. Precipitates were collected by centrifugation $(2000 \mathrm{~g}, 10 \mathrm{~min})$ and washed three times with Tris buffer ( 0.05 moles/liter, $\mathrm{pH} 8.0)$. A suspension of the insoluble material was assayed for Asnase activity.

\section{RESULTS}

Table I summarizes the pertinent clinical data and the results of immunological investigations on 11 patients who underwent therapy with Asnase. More complete information concerning the results and toxicity of therapy appears elsewhere (12). 29 of the patients studied did not have anaphylactic reactions to Asnase. None of these had any serologically detectable specific antibody to the enzyme preparation. In contrast, all six of the patients with generalized anaphylactic reactions had specific passive hemagglutinating antibodies detectable at least 1 day preceding the reaction when those samples were available, and those titers rose in the ensuing days after discontinuation of therapy (Fig. 1). Patient D. C. developed antibodies after two $1000 \mathrm{IU} / \mathrm{kg}$ doses of Asnase but never received further therapy with the enzyme. Four other patients were given no further daily therapy after they developed passive hemagglutination titers.

Both 19S mercaptoethanol-sensitive and 7S mercaptoethanol-resistant antibodies were found in every serum with passive hemagglutinating antibodies. Fig. 2 illustrates the results of sucrose gradient separation of the serum of patient $F$. Q. 21 days after the beginning of therapy with Asnase, 8 days after her anaphylactic reaction. The predominance of 19S ME-sensitive antibodies is seen, although 7S ME-resistant antibodies and intermediately sedimenting antibodies were also present. This mixture of mercaptoethanol-sensitive and -resistant antibodies is, of course, characteristic of a primary response to a protein antigen.

Two patients, V. W. and E. S., who had attained complete remissions of their leukemia after the first course of Asnase, subsequently developed antibodies to the enzyme when the course was repeated several months later as treatment for clinical relapse of their disease. One of these two, V. W., was not treated further after an antibody titer developed. The second, E. S., had a severe anaphylactic reaction 9 days after the start of the second course. Data relevant to E. S. are shown in Fig. 3. It is important to note that this patient was treated under a protocol in which she received only $10 \mathrm{IU} / \mathrm{kg}$ per day, or slightly less than $1 \mathrm{mg}$ of protein/day, during her first course. During the second course she received the more usual dose of $200 \mathrm{IU} / \mathrm{kg}$ per day. The

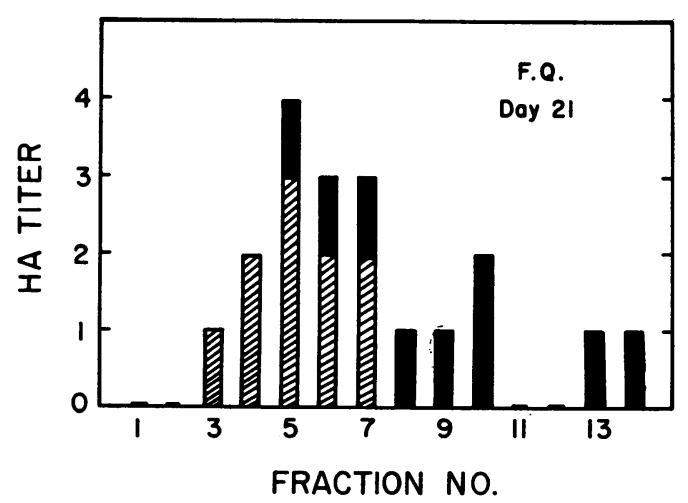

Figure 2 Centrifugal fractionation of serum from a primary response. Serum obtained from patient, F. Q., 21 days after her first injection of L-asparaginase was centrifuged in a $10-40 \%$ sucrose gradient at $50,000 \mathrm{rpm}$ for $8 \mathrm{hr}$. Solid portions of the bars represent the passive hemagglutination (HA) titer remaining after a $60 \mathrm{~min}$ incubation of the fraction in $0.1 \mathrm{M} 2$-mercaptoethanol at $37^{\circ} \mathrm{C}$. 


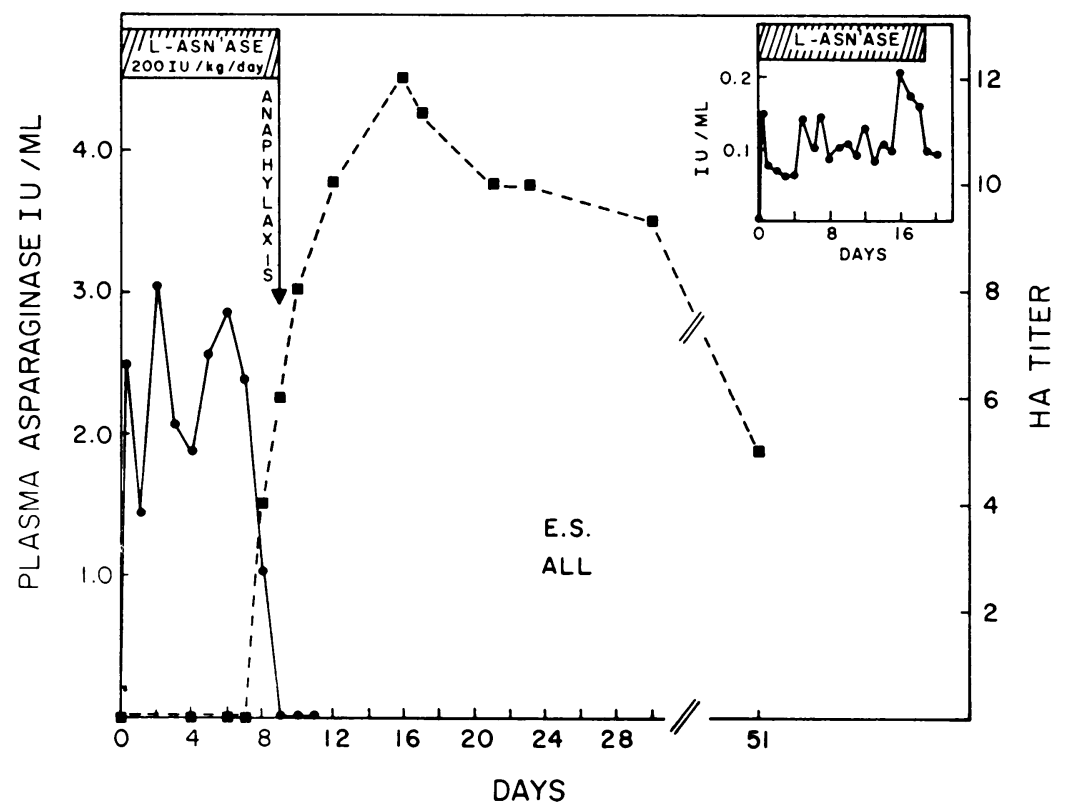

FigLRE 3 Comparison of enzyme level and immune response during a second course of therapy. The small graph in upper right represents the findings during first course of therapy in E. S. with L-asparaginase (10 IU/ $/ \mathrm{kg}$ per day). The solid line represents enzyme activity and the broken line passive hemagglutination (HA) titer.

immunological response was characteristic of a secondary (anamnestic) reaction with somewhat shorter latency than seen in the other patients, a more rapid rise in the

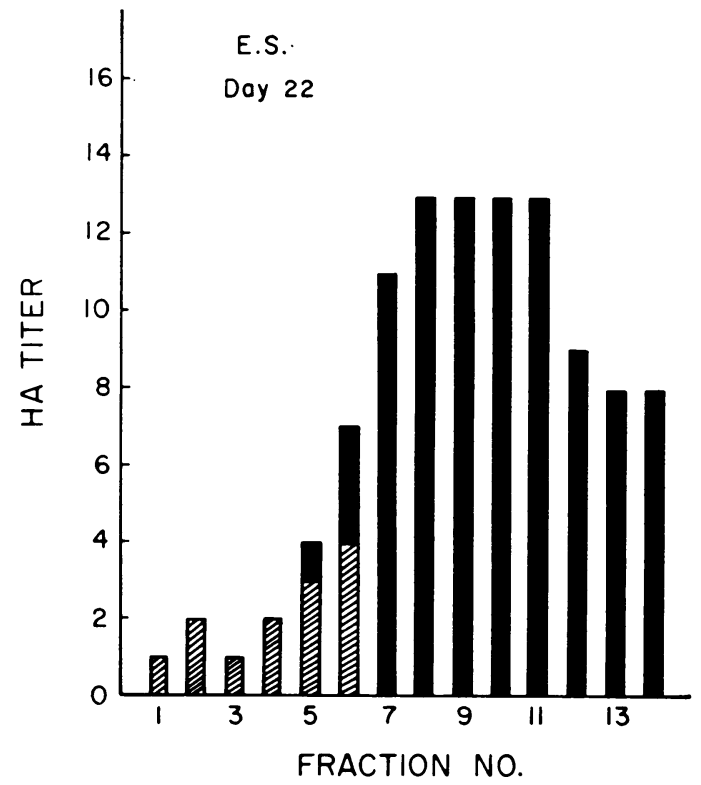

FIGCRE 4 Centrifugal fractionation of serum from a secondary response. Serum from patient E. S., 22 days after her first dose of the second course of I-asparaginase, 200 $\mathrm{IL} / \mathrm{kg}$ per day, was fractionated and plotted as described in Fig. 2. level of serum antibodies, and a higher, more sustained peak of antibody titer. Moreover, as shown in Fig. 4. when sucrose gradient ultracentrifugation was performed on serum drawn 12 days after the reaction, $7 \mathrm{~S}$ mercaptoethanol-resistant antibody was found to predominate with relatively little antibody activity in the $19 \mathrm{~S}$-sedimenting fractions. Antibody that sedimented in the $7 \mathrm{~S}$ region was found to predominate even on the 1st day of appearance of a passive hemagglutination titer. This response was in sharp contrast with patients that had been given only one course of enzyme. These findings suggest that lymphocytes of patient E. S. had been "primed" to produce antibodies by the low doses of Asnase during the first course even though serum antibodies were not detectable at that time.

Plasma levels of asparaginase. Plasma levels of 3-4 $\mathrm{IU} / \mathrm{ml}$ of Asnase were generally observed $24 \mathrm{hr}$ after intravenous administration of $200 \mathrm{IU} / \mathrm{kg}$ per day. In patients who had an anaphylactic reaction, the plasma Asnase level fell 1-3 days before the reaction (Fig. 1) with the exception of A. R. whose level fell 1 day after the allergic reaction. The reciprocal character of the fall in Asnase and rise of passive hemagglutination titer was evident and suggested that antigen-antibody complexes might have been formed in vivo, leading to more rapid elimination of the enzyme from the circulation by the reticuloendothelial system. One patient, V. W., showed a perplexing fall in enzyme levels without the concomitant 
appearance or rise in antibody titer during her first course of therapy, but developed antibodies during her second course of therapy, 11 months later.

Precipitation of antigen-antibody complexes formed in vitro. The ability of Asnase to form complexes with antibody was tested in vitro with sera from several patients. $2 \mathrm{IU}$ of Asnase was added to $1 \mathrm{ml}$ of serum in which free passive hemagglutinating antibody was detectable, and the mixture was incubated for $30 \mathrm{~min}$ at $4^{\circ} \mathrm{C}$. Controls included incubation of Asnase with sera taken before the onset of therapy, and immune sera to which no Asnase was added. $30 \%$ saturation with ( $\left.\mathrm{NH}_{4}\right)_{2} \mathrm{SO}_{4}$ was found to insolubilize the complexes formed. Only complexed antigen and antibody were differentially precipitated at $30 \%$ saturation, whereas Asnase and unbound immunoglobulins remained soluble. At $40 \%$ saturation or more, both free Asnase and unbound immunoglobulins were precipitated together with the complexes. Double diffusion in agar against specific goat antihuman globulins identified the classes of antibody present in the precipitate. By this means $\operatorname{IgA}, \operatorname{IgM}$, and IgG all were found in $30 \%$ saturated $\left(\mathrm{NH}_{4}\right)_{2} \mathrm{SO}_{4}$ precipitates containing specific antibody and Asnase. Unfortunately, we could not identify complexes that may have been formed in vivo in sera immediately antedating the time of anaphylaxis by direct $30 \%$ saturated ammonium sulfate fractionation, probably because the levels were too low to detect. It should be noted that Asnase activity was still detectable in the complex and, in fact, was found there almost exclusively rather than in the supernatant fluid of samples from the three patients tested on days after their anaphylactic reactions (Fig. 5).

Inactivation of enzyme by rabbit antibody. Use of a high titered rabbit antiserum to the same preparations of Asnase used in our patients enabled us to demonstrate why Asnase activity was not lost in precipitates of antigen-antibody complexes. As shown in Fig. 6, it proved impossible to inactivate the sample containing the enzyme and antibody beyond $50 \%$ of the enzyme activity even at antibody excess. When the samples were centrifuged, all of the activity was found to be in the precipitate. A similar result was also obtained with serum from patient $\mathrm{E}$. S.

Reaction of antibody with pure enzyme. In order to determine whether at least a portion of the antibodies made in these patients was to the enzyme itself rather than solely to contaminants in the therapeutic preparation, $10 \mathrm{IU}$ of Asnase (antigen excess) was incubated with $0.5 \mathrm{ml}$ of serum from patient E. S. (day 22) for $30 \mathrm{~min}$ at $37^{\circ} \mathrm{C}$. The mixture was fractionated on a 10 $40 \%$ linear sucrose gradient. As a control, serum obtained on a day previous to the initiation of therapy in which no antibody was detectable, was incubated with the same amount of Asnase. Free Asnase was found in the $7 \mathrm{~S}$ region of the control gradient, but a shift of Asnase activity was identified in the experimental gradient, consistent with the formation of a complex more dense than the enzyme alone (Fig. 7). The smearing of activity suggested various degrees of

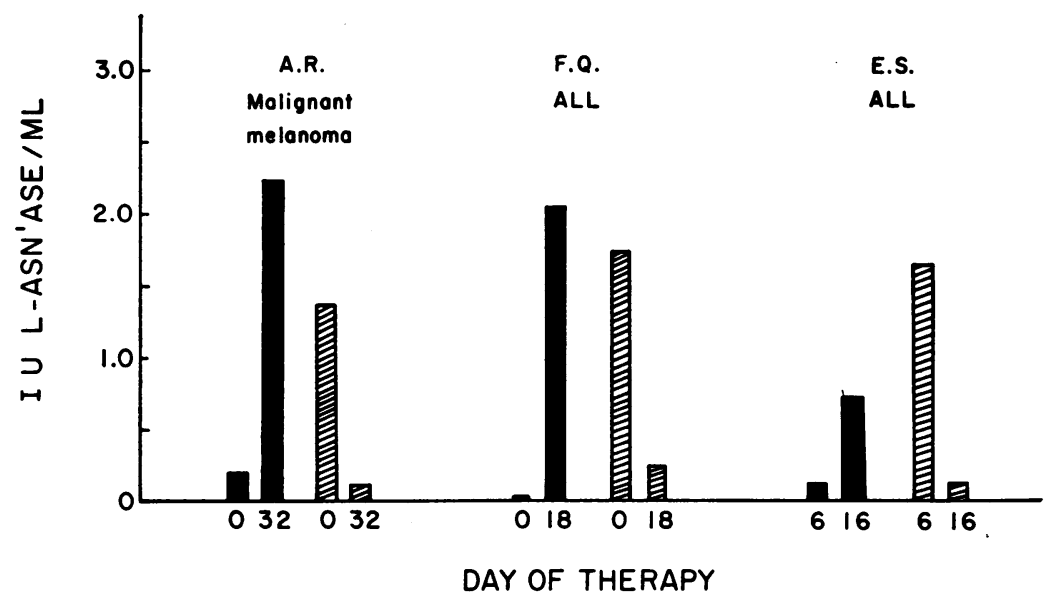

FIGURe 5 Ammonium sulfate precipitation of enzyme-antibody complexes. LAsparaginase (2 IU) was added to $0.5 \mathrm{ml}$ of serum from each patient and incubated at $4^{\circ} \mathrm{C}$ for $30 \mathrm{~min}$. A saturated solution of $\left(\mathrm{NH}_{4}\right)_{2} \mathrm{SO}_{4}\left(4^{\circ} \mathrm{C}\right)$ was added slowly with mixing to a final concentration of $30 \%$ saturation. Samples were incubated for an additional $15 \mathrm{~min}$ at $4^{\circ} \mathrm{C}$ and centrifuged at $5000 \mathrm{~g}$ for $10 \mathrm{~min}$. Precipitates were washed twice with a cold $30 \%$ saturated solution of $\left(\mathrm{NH}_{4}\right)_{2} \mathrm{SO}_{4}$ and dissolved in Tris buffer $(0.05$ mole/liter, $\mathrm{pH} 8.0)$. Solid bars represent $\mathrm{I}$-asparaginase activity in the precipitates; hatched bars represent the activity in serum after removal of precipitate. 


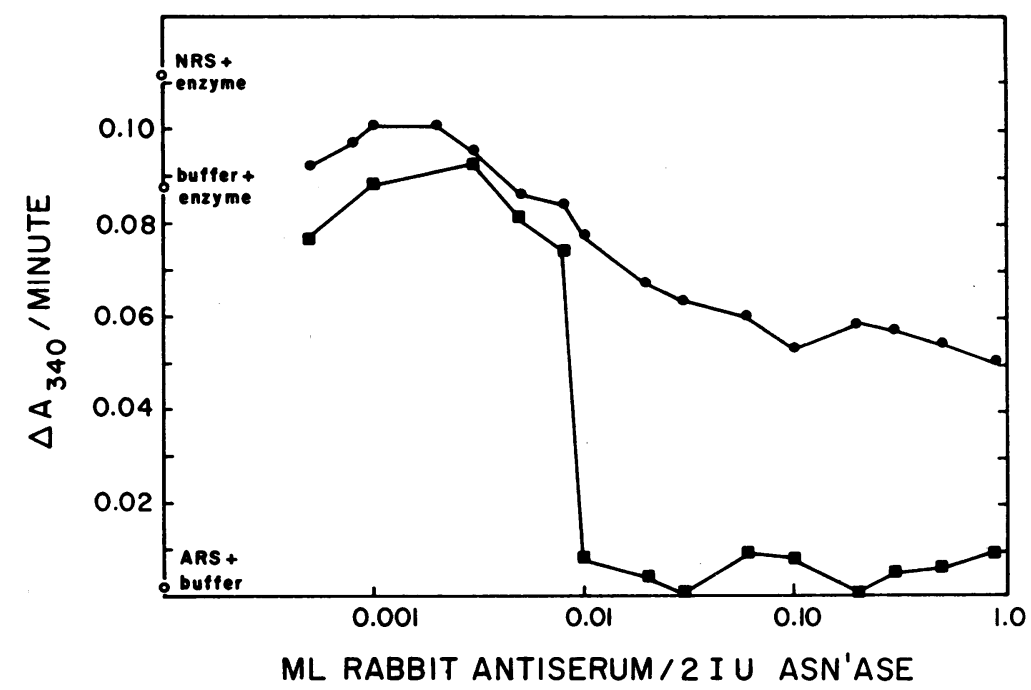

FIGURE 6 Titration of L-asparaginase activity with hyperimmune rabbit serum. Rabbit antiserum to L-asparaginase was added to $2 \mathrm{IU} \mathrm{L}$-asparaginase in Tris buffer $(0.05$ mole/liter, $\mathrm{pH} 8.0)$ and incubated at $4^{\circ} \mathrm{C}$ for $30 \mathrm{~min}$. Samples were removed for enzyme assay (solid circles); the remainder of the incubation mixture was centrifuged at $2000 \mathrm{~g}$ for $10 \mathrm{~min}$, and the supernatant fluid was assayed for enzyme activity (solid squares).

complex formation by the different populations of antibodies formed in response to the enzyme.

Precipitins. In only one of the six patients with allergic reactions could precipitating antibodies be demonstrated. Patient E. S. produced precipitin antibodies to at least three components of the Asnase preparations, the innermost one of which was presumably the enzyme

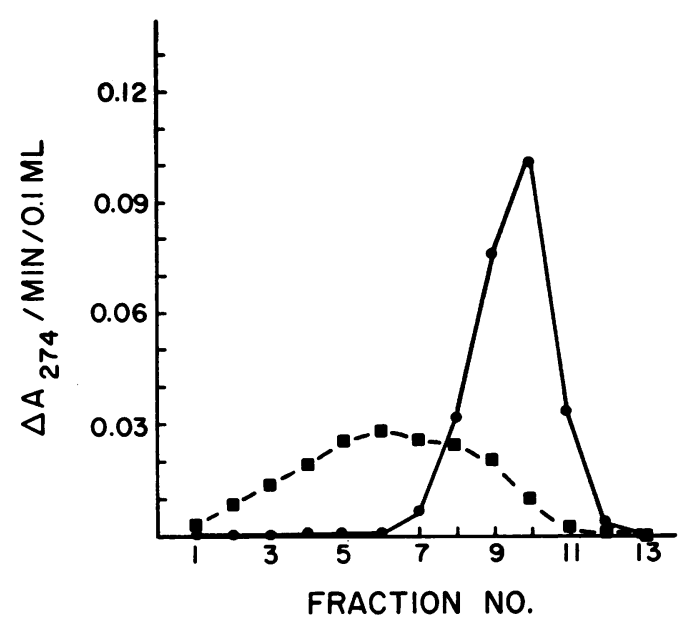

FIGURE 7 Centrifugal analysis of the effect of hyperimmuse serum on L-asparaginase activity. An L-asparaginase solution $(0.3 \mathrm{ml}, 15 \mathrm{IU})$ in either Tris buffer $(0.05 \mathrm{~mole} / \mathrm{liter}, \mathrm{pH}$ 8.0 ) or serum from patient E. S. (day 22) was centrifuged in a $5 \mathrm{ml}$ linear $10-40 \%$ sucrose gradient at $50,000 \mathrm{rpm}$ for $8 \mathrm{hr}$ at $4^{\circ} \mathrm{C}$. The control activity is shown by circles, and the serum-treated sample activity by squares. itself (Fig. 8). A preparation of Asnase essentially homogeneous by electrophoresis showed only a single line of identity with the innermost line of the less pure preparation.

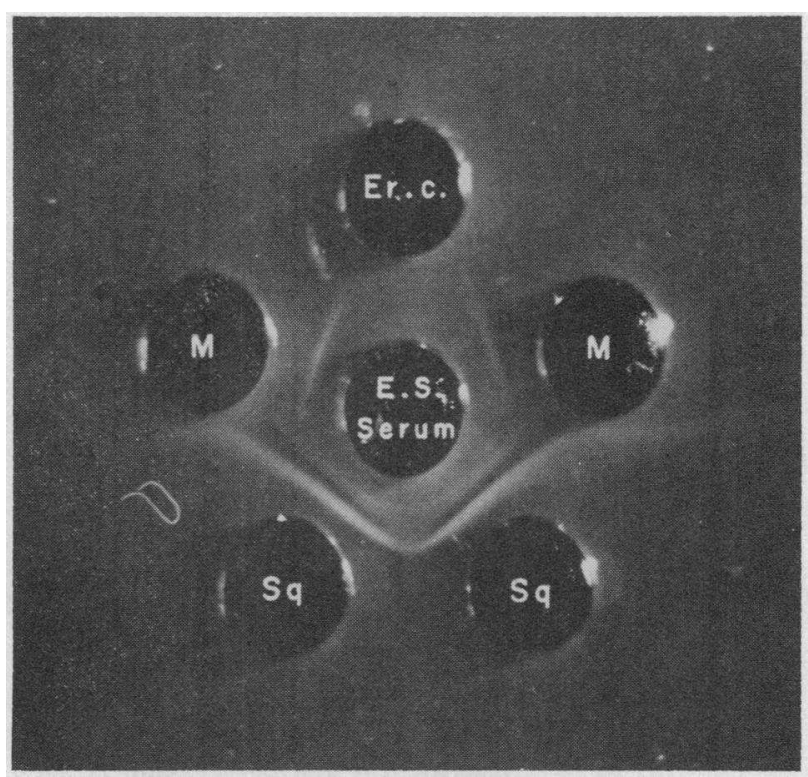

Figure 8 Ouchterlony double diffusion in agar. E. S. serum was concentrated twofold by vacuum dialysis before use. $M=L$-asparaginase from Merck Sharpe \& Dohme $(5 \mu \mathrm{g}$ per well); Sq $=$ L-asparaginase from E. R. Squibb \& Sons (5 $\mu \mathrm{g}$ per well) ; Er. c. = L-asparaginase from $E$. carotovora (5 $\mu \mathrm{g}$ per well). 


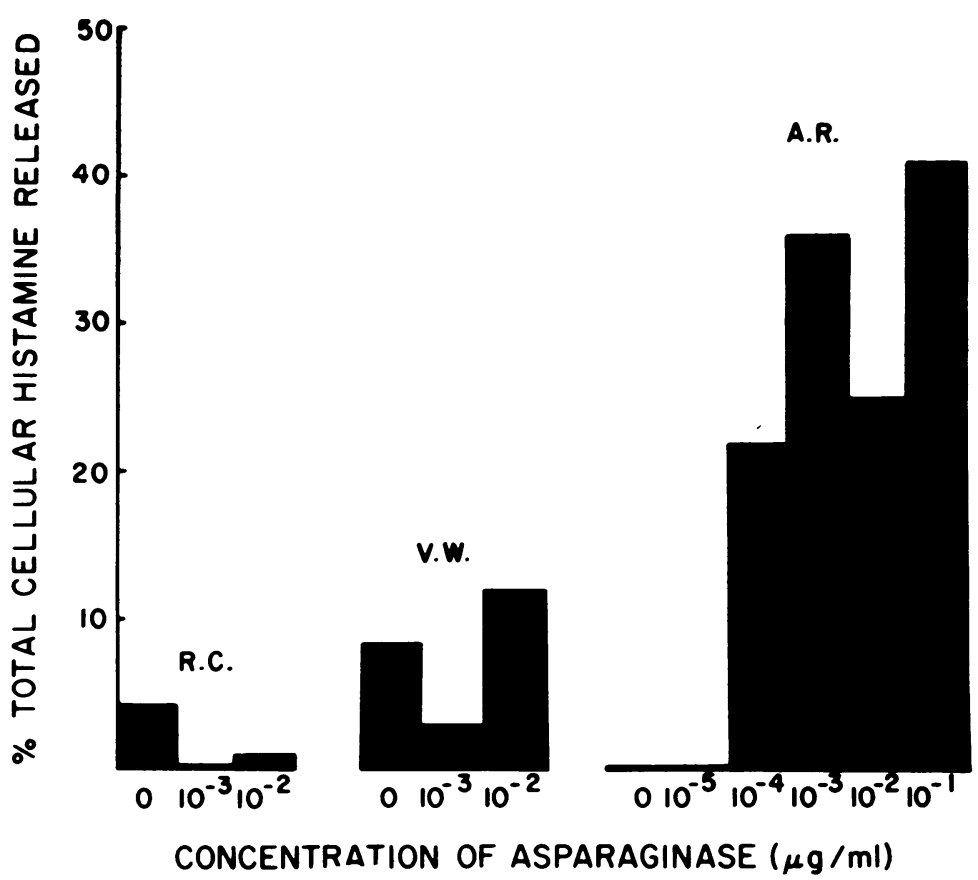

FIGLRE 9 Histamine release from leukocytes of patients. R. C., normal volunteer. V. IV., a patient who received I-asparaginase but did not have an allergic reaction; leukocytes were collected from this patient before her second course. A. R., a patient who sustained an anaphylactic reaction 14 days before collection of leukocytes for the test.

Asnase from E. carotovora did not show any crossreaction with $E$. coli Asnase by this method. However, when serum from a rabbit immunized against $E$. carotor'ora Asnase was tested against GRBC's sensitized with $E$. coli Asnase, a titer of 3 was obtained. It must therefore be concluded that mild cross-reactivity exists between Asnase's from these two bacterial sources.

Complement-fixing antibodics. Sera from five patients with immunological reactions were tested, and all had complement-fixing antibodies to the Asnase preparation demonstrable on the 12 th day after initiation of therapy and thereafter. The optimal concentration of Asnase for this test was approximately $0.125 \mu \mathrm{g} / \mathrm{ml}$.

Reagins ( $I g E)$. Attempts to demonstrate a quantitative increase in serum $\operatorname{IgE}$ by microimmunodiffusion were unsuccessful in all of our patients. However, histamine release was demonstrable after incubation of peripheral blood leukocytes from patient A. R. with Asnase in vitro, indicative of cell-bound IgE (Fig. 9). Leukocytes obtained after an initial course of therapy from V. W., who had demonstrated a fall in enzyme levels but no detectable antibody, failed to release histamine. Similarly, leukocytes from an individual who had not received Asnase but was known to have a seasonal pollen allergy, did not release histamine. A patient,
R. P., with a febrile reaction to Asnase also failed to show specific $\operatorname{IgE}$ antibody by this reaction. We were unable to interpret tests performed on three other children because the total cellular content of histamine was too low.

\section{DISCUSSION}

Coombs and Gell (28) have classified allergic reactions to drugs and foreign proteins as anaphylactic, hemolytic, and inflammatory, serum-sickness, and delayed hypersensitivity. All of the adverse allergic reactions encountered in the present study consisted of generalized anaphylaxis as characterized by hypotension, cyanosis, respiratory stridor, edema, and in one instance, coma. The intravenous route of administration may have been a major factor, but other investigators have encountered a broader spectrum of allergic reactions with a higher incidence of mild urticaria $(2-4,6,11)$ despite the fact that they used enzyme from the same pharmaceutical firms and the same route of administration. Only one of the patients in this study who showed an allergic reaction had a history of allergy.

The presence of specific IgE antibody fixed to circulating leukocytes could be demonstrated in only one adult patient principally because of the very low hista- 
mine content of leukocytes from the leukemic children. This may be attributable to the cytotoxic agents many of these children were receiving when the histamine release assay was performed. An indirect test passively sensitizing normal leukocytes with sera from these patients may circumvent this difficulty (29). Since the test for reagins by histamine release was complex and was limited by the low histamine content of the leukocytes, this procedure was not useful in this study to document the presence of $\operatorname{IgE}$ antibodies in reactors. Skin testing was likewise rejected because, aside from the hazard of eliciting a severe anaphylactic reaction by skin testing, a further serious objection is its failure to predict absolutely whether allergic reactions will occur when the agent tested is given by a route other than intradermally. It has been shown by others (30) that complement-fixing antibodies bear no apparent relationship to either the tissue sensitizing reagins or to socalled "blocking" antibodies, the IgG antibodies produced in high titer during desensitization procedures, but which may also be formed during the natural course of allergic sensitization (31).

There is ample precedent for using passive hemagglutination as a method of detecting antibodies associated with allergic reactions to drugs or foreign proteins $(32,33)$ as well as to pollen allergens $(34,35)$. Extensive investigations by Sehon, Gyenes, and Kisil (31) have indicated that passive hemagglutinating antibodies against ragweed pollen are more closely correlated with IgG antibodies than with $\operatorname{IgE}$ antibodies. Nevertheless, it appears from this study that reaginic antibodies and passive hemagglutinating antibodies to Asnase are produced simultaneously in man and that, therefore, the passive hemagglutination reaction may be useful in predicting serious anaphylaxis. A simultaneous rise in reagins and "other antibodies" was also found by others using different methods (36). In the current study, the rise in antibody titer was particularly striking when coupled with a rapid fall in previously stable levels of Asnase in the serum. It is suggested that this fall was a manifestation of accelerated clearance of antigen-antibody complexes by the reticuloendothelial system. A recent preliminary report, however, (37) has indicated a lack of correlation between decreased enzyme levels and allergic reactions. Although only one patient in our series did not manifest such an association, passive hemagglutinating antibodies were not determined in the other study, and it is thus difficult to make a direct comparison with those results. It remains to be determined whether minor anaphylactoid reactions such as urticaria may occur after passive hemagglutinating antibodies appear in the serum as suggested by patient L. T. in this study, or whether a degree of sensitization sufficient to cause a positive passive hemagglutination titer invariably leads to anaphylactic shock.

Although precipitin lines could not always be detected by the Ouchterlony technique, in contrast with two other reports in which a higher incidence of precipitin formation was observed $(17,38)$, the precipitation of soluble complexes of Asnase and antibody with $30 \%$ saturated ammonium sulfate after previous addition of Asnase to serum with a positive passive hemagglutination titer, demonstrated that such complexes were formed. Considerable amounts of IgG and IgM antibodies were detectable in the antigen-antibody complexes precipitated with $30 \%$ saturated ammonium sulfate. The unavailability of an antiserum against $\operatorname{IgE}$ at the time of this study precluded the demonstration of reagins that may also have been present in the complexes. Both precipitates and soluble complexes retained enzymatic activity, and it was impossible to inactivate the enzyme beyond $50 \%$ even in the zone of antibody excess. A similar lack of complete inactivation by immune serum has been reported (39). This indicates that the antibody does not bind directly at the active site of the enzyme but may limit accessibility of the substrate to the active site. Furthermore, Asnase inactivated by a specific active site reagent, 5-diazo-4-oxo-L-norvaline (20), gave a line of identity with native Asnase by Ouchterlony double diffusion in agar. Since the enzyme is a tetramer with four catalytic sites (20), the antigenantibody complex may still leave an active site exposed. Sequestration of enzymatically active antigen-antibody complexes in the reticuloendothelial system might thus account for the prolonged absence of L-asparagine in the plasma after the disappearance of detectable levels of Asnase in the circulation $(12,40)$.

\section{ACKNOWLEDGMENTS}

The expert technical assistance of Miss Ellen Webber, Miss Marilee Wellersdick, and Miss Celeste Gaumond is acknowledged. Clinical collaboration of Dr. Robert L. Capizzi and Dr. Joseph R. Bertino made this work possible. We are indebted to Dr. Byron H. Waksman and Dr. Henry P. Treffers for their advice.

One of the authors, Dr. Mitchell, is a Scholar of the Leukemia Society of America, and Dr. Handschumacher is an American Cancer Society Professor of Pharmacology. Support of Mr. Peterson was derived from a Medical Scientist Training Program grant (GM02044). This work was supported by grants from the American Cancer Society (T112 and In-31-J-2) and the U. S. Public Health Service (CA5012 and CA10748).

\section{REFERENCES}

1. Dolowy, W. C., D. Henson, J. Cornet, and H. Sellin. 1966. Toxic and antineoplastic effects of L-asparaginase. Study of mice with lymphoma and normal monkeys and a report on a child with leukemia. Cancer. 19: 1813. 
2. Hill, J. M., J. Roberts, E. Loeb, A. Kahn, A. MacLellan, and R. W. Hill. 1967. L-Asparaginase therapy for leukemia and other malignant neoplasma: remission in human leukemia. J. Amer. Med. Ass. 202: 882.

3. Oettgen, H. F., L. J. Old, E. A. Boyse, H. A. Campbell, F. S. Philips, B. D. Clarkson, L. Tallal, R. D. Leeper, M. K. Schwartz, and J. H. Kim. 1967. Inhibition of the leukemias in man by L-asparaginase. Cancer Res. 27: 2619.

4. Haskell, C. M., G. P. Canellos, B. G. Leventhal, P. P. Carbone, J. B. Block, A. A. Serpick, and O. S. Selawry. 1969. L-Asparaginase. Therapeutic and toxic effects in patients with neoplastic disease. $N$. Engl. J. Med. 281: 1028.

5. Capizzi, R. L., R. G. Peterson, D. A. Cooney, W. A. Creasey, and R. E. Handschumacher. 1969. L-Asparaginase therapy of acute leukemia: biochemical and clinical observations. Proc. Amer. Ass. Cancer Res. 10: 12.

6. Whitecar, J. P., Jr., G. P. Bodey, J. E. Harris, and E. J. Freireich. 1970. L-Asparaginase. N. Engl. J. Med. 282: 732.

7. Mathé, G., J. L. Amiel, L. Schwarzenberg, M. Schneider, A. Cattan, J. R. Schlumberger, M. Hayat, F. DeVassal, C. Jasmin, and C. Rosenfeld. 1969. Essai de traitement de la leucémie aigue lymphoblastique par la L-asparaginase. Presse Med. 77: 461.

8. Hill, J. M., E. Loeb, A. MacLellan, A. Kahn, J. Roberts, W. F. Schields, and N. O. Hill. 1969. Response to highly purified L-asparaginase during therapy of acute leukemia. Cancer Res. 29: 1574.

9. Ohnuma, T., J. F. Holland, G. Nagel, and G. St. Arneault. 1969. Effects of L-asparaginase in acute myelocytic leukemia. J. Amer. Med. Ass. 210: 1919.

10. Clarkson, B., I. Krakoff, J. Burchenal, D. Karnof sky, R. Golbey, M. Dowling, H. Oettgen, and A. Lipton. 1970. Clinical results of treatment with E. coli L-asparaginase in adults with leukemia, lymphoma, and solid tumors. Cancer. $25: 279$.

11. Tallal, L., C. Tan, H. Oettgen, N. Wollner, M. McCarthy, L. Helson, J. Burchenal, D. Karnofsky, and M. L. Murphy. 1970. E. coli L-asparaginase in the treatment of leukemia and solid tumors in 131 children. Cancer. 25: 306.

12. Capizzi, R. L., J. R. Bertino, R. T. Skeel, W. A. Creasey, R. Zanes, C. Olayon, R. G. Peterson, and R. E. Handschumacher. 1971. L-Asparaginase: clinical, biochemical, pharmacological and immunological studies. Ann. Intern. Med. In press.

13. Whelan, H. A., and J. C. Wriston, Jr. 1969. Purification and properties of asparaginase from Escherichia coli B. Biochemistry. 8: 2386.

14. Roberts, J., M. D. Prager, and N. Bachynsky. 1966. The antitumor activity of Escherichia coli L-asparaginase. Cancer Res. 26: 2213.

15. Schein, P. S., N. Rakieten, B. M. Gordon, R. D. Davis, and D. P. Rall. 1969. The toxicity of Escherichia coli L-asparaginase. Cancer Res. 29: 426.

16. Peterson, R. G., M. S. Mitchell, R. L. Capizzi, and R. E. Handschumacher. 1969. Immunological modification of L-asparaginase activity. Pharmacologist. 11: 234.

17. Oettgen, H. F., P. A. Stephenson, M. K. Schwartz, R. D. Leeper, L. Tallal, C. C. Tan, B. D. Clarkson, R. B. Golbey, I. H. Krakoff, D. A. Karnofsky, M. L. Murphy, and J. H. Burchenal. 1970. Toxicity of E. coli L-asparaginase in man. Cancer. 25: 253.
18. Cooney, D. A., and R. E. Handschumacher. 1968. Investigation of L-asparagine metabolism in animals and human subjects. Proc. Amer. Ass. Cancer Res. 9: 6.

19. Cooney, D. A., R. L. Capizzi, and R. E. Handschumacher. 1970. Evaluation of L-asparagine metabolism in animals and man. Cancer Res. 30: 929.

20. Jackson, R. C., and R. E. Handschumacher. 1970. Escherichia coli L-asparaginase. Catalytic activity and subunit nature. Biochemistry. 9: 3585.

21. Stavitsky, A. B. 1954. Micromethods for the study of proteins and antibodies. I. Procedure and general applications of hemagglutination and hemagglutination-inhibition reactions with tannic acid and protein-treated red blood cells. J. Immunol. 72: 360 .

22. Mitchell, M. S., M. E. Wade, R. C. DeConti, J. R Bertino, and P. Calabresi. 1969. Immunosuppressive effects of cytosine arabinoside and methotrexate in man. Ann. Intern. Med. 70: 535.

23. Levine, L. 1967. Micro-complement fixation. In Handbook of Experimental Immunology. D. M. Weir, editor. F. A. Davis Co., Philadelphia. 707.

24. Lichtenstein, L. M., and A. G. Osler. 1964. Studies on the mechanisms of hypersensitivity phenomena. IX. Histamine release from human leukocytes by ragweed pollen antigen. J. Exp. Med. 120: 507.

25. Shore, P. A., A. Burkhalter, and V. H. Cohn, Jr. 1959. A method for the fluorometric assay of histamine in tissues. J. Pharmacol. Exp. Ther. 127: 182.

26. Kremzner, L. T., and I. B. Wilson. 1961. A procedure for the determination of histamine. Biochim. Biophy's. Acta. 50: 364.

27. Sahiar, K., and R. S. Schwartz. 1965. The immunoglobulin sequence. I. Arrest by 6-mercaptopurine and restitution by antibody, antigen or splenectomy. J. Immunol. 95: 345 .

28. Coombs, R. R. A., and P. G. H. Gell. 1963. The classification of allergic reactions underlying disease. In Clinical Aspects of Immunology. P. G. H. Gell and R. R. A. Coombs, editors. Blackwell Scientific Publications Ltd., Oxford. 317.

29. Levy, D. A., and A. G. Osler. 1966. Studies on the mechanisms of hypersensitivity phenomena. XIV. Passive sensitization in vitro of human leukocytes to ragweed pollen antigen. J. Immunol. 97: 203.

30. Portnoy, J., and W. B. Sherman. 1954. Complement fixation studies in ragweed allergy. II. Determination of antibody in human sera to ragweed antigen by means of a complement fixation inhibition test; the relationship of antibody so determined to the passive transfer for blocking antibody. J. Allergy. 25: 229.

31. Sehon, A. H., L. Gyenes, and F. T. Kisil. 1967. Antibodies in sera of allergic individuals. Mod. Trends Immunol. 2: 188.

32. Schwartz, R. H., and J. H. Vaughan. 1963. Immunologic responsiveness of man to penicillin. J. Amer. Med. Ass. 186: 1151.

33. Arbesman, C. E., S. Z. Kantor, N. R. Rose, and E. Witebsky. 1960. Serum sickness. Serologic studies following prophylactic tetanus antitoxin. J. Allergy. 31: 257.

34. Gordon, J., B. Rose, and A. H. Sehon. 1958. Detection of "non-precipitating" antibodies in sera of individuals allergic to ragweed pollen by an in vitro method. $J$. Exp. Med. 108: 37. 
35. Frick, O. L., L. Gyenes, and A. H. Sehon. 1960. Demonstration of antibodies in the sera of grass-sensitive persons by the bis-diazotized-benzidine hemagglutination technique. J. Allergy. 31: 216.

36. Dohlwitz, A., S. Franzen, A. Holmgren, A. Killander, D. Killander, L. Wide, and L. Ahstrom. 1970. Studies on antibody formation in patients treated with L-asparaginase. In Experimental and Clinical Effects of L-Asparaginase. E. Grundmann and H. F. Oettgen, editors. Springer-Verlag, Berlin. 198.

37. Dunnicliff, M. A., E. A. Eigner, N. Jaffe, D. Traggis, and V. M. Rosenoer. 1970. Plasma asparaginase con- centrations and the prediction of anaphylactic reactions. Proc. Amer. Ass. Cancer Res. 11: 22.

38. Pinsky, C. M., S. Mitchell, H. F. Oettgen, and M. K. Schwartz. 1970. Immune reactions to L-asparaginase in man. Proc. Amer. Ass. Cancer Res. 11: 63.

39. Khan, A., and J. M. Hill. 1969. Neutralizing precipitin in the serum of a patient treated with L-asparaginase. J. Lab. Clin. Med. 73: 846.

40. Miller, H. K., J. S. Salser, and M. E. Balis. 1969. Amino acid levels following $\mathrm{L}$-asparagine amidohydrolase (E.C. 3.5.1.1) therapy. Cancer Res. 29: 183. 